\title{
USE OF DIFFERENT OPTIONS OF ANTI-INFLAMMATORY THERAPY IN PATIENTS WITH SEVERE COVID-19
}

\section{Vita Skoryk}

The aim of the study. To compare the effectiveness of methylprednisolone, dexamethasone and tocilizumab in patients with severe coronavirus disease. Identify the most appropriate treatment option.

Materials and methods. Patients of group $1(n=20)$ received for anti-inflammatory purposes tocilizumab at a dose of 600-800 mg. Patients in group $2(n=82)$ received pulse therapy with methylprednisolone. Patients in group 3 (n=20) received dexamethasone $6 \mathrm{mg} /$ day. Data are presented as M [25-75]. Statistical analysis of the results was performed using the program "Statistica 10". Significance of differences in indicators was assessed using the nonparametric Wilcoxon test. The results were considered reliable at values of $p<0.05$.

Results. The severe course of coronavirus disease with the development of cytokine storm and respiratory distress syndrome is characterized by an increase in markers of inflammation: in group 1 the median CRP was $89.2 \mathrm{~g} /$, in group $2-64.2 \mathrm{~g} / \mathrm{l}$, and in $3-76.2 \mathrm{~g} / \mathrm{l}$, and did not differ significantly between groups ( $p>0.05)$. The level of IL-6 in group 1 was $61.8 \mathrm{pg} / \mathrm{ml}$, in group $2-64.6 \mathrm{pg} / \mathrm{ml}$, and in group $3-46.5 \mathrm{pg} / \mathrm{ml}$ without significant differences between groups $(p>0.05)$. The level of ferritin in all groups exceeded normal values.

Conclusions The most favourable result was obtained when using methylprednisolone: it was possible to reduce the mortality rate to $59.8 \%$. The relative risk of developing VTE was significantly higher in groups 1 and 3 (RR12 6.8 [2.7-16.8] p12<0.0001, RR23 0.15 [0.06-0.35] p23<0.0001), which gives grounds to confirm the presence of anticoagulant activity in methylprednisolone

Keywords: SARS-nCoV-2, COVID-19, hypoxemic respiratory failure, acute respiratory distress syndrome, respiratory support, cytokine storm

How to cite:

Skoryk, V. (2021). Use of different options of anti-inflammatory therapy in patients with severe COVID-19. ScienceRise: Medical Science, 5 (44), 22-27. doi: http://doi.org/10.15587/2519-4798.2021.241013

(C) The Author(s) 2021

This is an open access article under the Creative Commons CC BY license hydrate

\section{Introduction}

Although most patients with COVID-19 have mild to moderate disease, almost a third of patients are at high risk of developing more severe disease with acute respiratory distress syndrome (ARDS), which may require hospitalization to intensive care with mechanical ventilation and a high probability of death [1]. The main mechanisms of formation of severe COVID-19 are associated with systemic inflammatory reactions that can lead to lung damage and multiple organ failure [2-4]. Uncontrolled inflammatory response and hypercoagulation in COVID-19 is similar to the course of ARDS other etiology, for which today there is evidence for the use of corticosteroids to reduce inflammation, coagulation and fibroproliferative processes. Based on this assumption, systemic anti-inflammatory drugs have been proposed as an alternative treatment to address the inflammatory condition caused by SARS-CoV-2 and reduce mortality in these patients $[5,6]$.

The main mechanism of the pathogenesis of severe and critical COVID-19 is the activation of the hyperimmune response, which over time coincides with a decrease in viral load and is called a "cytokine storm".
The key tool for triggering a cytokine storm is IL-6, which activates Janus kinase with soluble receptors and thus opens the way to avalanche-like production of acute phase reactants and other molecules that activate immunocompetent cells and endothelial damage [7]. The discovery of the role of these mechanisms in the progression of coronavirus disease has given rise to the search for various areas of immunosuppressive and immunomodulatory therapy, which aims to "quench" the "cytokine storm" as soon as possible. Among the areas of treatment discussed in the literature are corticosteroids and soluble IL-6 receptor blockers, tocilizumab [8].

The first strong justification for the use of steroids in COVID-19 was a preliminary report of a randomized controlled trial conducted in the UK and published in June 2020 - RECOVERY. More than 6,000 patients were randomized to receive dexamethasone $(6 \mathrm{mg}$ daily for 10 days - 2104 patients) and did not receive dexamethasone (4321 patients). The use of dexamethasone has been shown to reduce mortality compared with conventional treatment of hospitalized patients with COVID-19 [9].

At the same time, the effectiveness of methylprednisolone is being studied. According to the 
fifth version of the Chinese treatment protocols COVID19, patients with severe course received methylprednisolone (1-2 mg/kg 5-7 days iv). In the methylprednisolone group, patients were less likely to need to be switched to invasive lung ventilation [10]. They also noted a faster decrease in levels of C-reactive protein and interleukin-6. The length of stay in ICU was significantly shorter in patients treated with methylprednisolone (8 days compared with 15 days). Due to monitoring in this group there were no serious complications caused by treatment with methylprednisolone.

A single-center retrospective cohort study using pulse methylprednisolone therapy was performed at the University Clinic of Madrid. There was a reduction in nosocomial mortality in patients receiving methylprednisolone by $41.8 \%$ compared with treatment without steroids [11].

However, many clinically important issues remain. Are the efficacy and optimal dosage of corticosteroids different for different ARDS phenotypes? Should corticosteroids be administered individually based on a clinical response or biomarkers such as C-reactive protein? What is the severity of the disease at which corticosteroids are now indicated? Should other potentially active therapeutics be administered with steroids? As there are still many controversial issues regarding the use of anti-inflammatory drugs in the treatment of COVID-19, there is a need to further study their effectiveness [12].

The aim of the research: to compare the effectiveness of methylprednisolone, dexamethasone and tocilizumab in patients with severe coronavirus disease. Identify the most appropriate treatment option.

\section{Materials and methods}

The study was conducted in 2020-2021 at the Department of Anesthesiology, Pediatric Anesthesiology and Intensive Care of the Kharkiv Medical Academy of Postgraduate Education on the basis of the Kharkiv Regional Clinical Infectious Diseases Hospital. The study included 122 patients with a mean age of $65.0 \pm 13.0$ years.

The work was carried out in accordance with the Code of Ethics of the World Medical Association (Helsinki Declaration). The work is allowed by the Biotic Commission of the Kharkiv Medical Academy of Postgraduate Education No. 2 14.09.2021). All patients included in the study provided written informed consent.

The diagnosis of coronavirus disease was determined according to the criteria proposed by the WHO and the current guidelines of the Ministry of Health of Ukraine [13-16]. The diagnosis of ARDS was established according to the Berlin criteria of 2012 [17].

All patients included in the study were carefully examined and the severity of their condition was assessed on the scales COVID-19 Critical Illness Prediction Tool (COVID-GRAM), COVID-19 Prognostic Tool. The median values obtained using COVID-GRAM were 245.0 [222.0-265.0] points, which corresponds to a high risk of developing critical conditions.

Verification of pneumonia was performed by computed tomography or chest radiography cavity. All patients underwent daily bedside ultrasound examination of the lungs with the determination of profiles A, B, pathological B and C and echocardioscopy in M-mode using an ultrasound scanner "Ultima PA" (Ukraine). End-diastolic (EDD) and end-systolic (ESD) dimensions of the left ventricle and right ventricular EDD were measured. On the basis of the obtained data according to the formula of Teichholz L. et al., (1976) the calculation of end-systolic (ESV) and end-diastolic volumes (EDV) of the left ventricle, stroke volume (SV), ejection fraction (EF) was performed.

Cardiac output (CO) was calculated by the formula:

\section{$\mathrm{CO}=\mathrm{SV} \times \mathrm{HR}$}

Cardiac index (CI) was calculated by the formula:

\section{$\mathrm{CI}=\mathrm{CO} / \mathrm{BSA}$,}

where BSA is the body surface area according to the Mostller formula. In the presence of an ultrasound window, the mean arterial pressure in the pulmonary artery (MAP PA) was measured by Kitabatake A et al. (1983). formula:

Body mass index (BMI) was calculated by the

$$
\mathrm{BMI}=\text { body weight } / \text { height } 2(\mathrm{~kg} / \mathrm{m} 2)
$$

Clinical blood test was performed using the analyzer "BC - 2800 Mindray" (PRC). Blood glucose levels were determined by glucose oxidase method, total bilirubin - using vanadic acid, ALT - by kinetic method (Cormay kits, Poland). Creatinine in the blood was determined by the Jaffe method.

The concentration of LDH was determined by the kinetic method, the content of total venous blood protein using the biuret method, albumin - with bromochrysol green (Granum kits, Spain). The content of C-reactive protein (CRP) was determined by turbidimetric method (Biosystems kits, Spain). Ferritin was determined by immunochemiluminescence analysis. The level of IL-6 was determined by enzyme-linked immunosorbent assay ( $\mathrm{eBi}$ oscience kits, USA). To monitor the state of the hemostasis system, the D-dimer was determined by ELISA (Vector-Best kits, Ukraine). All biochemical studies were performed on an automatic biochemical analyzer "Chemray 120 Mindray" (PRC).

Monitoring of patients was performed using Comen monitors (PRC) and included electrocardiography to determine heart rate (HR), measurement of systolic, diastolic (ATd) and mean arterial pressure (MAP) by oscillometric method and pulse oximetry $(\mathrm{SpO} 2)$.

Depending on the tactics of cytokine storm therapy, patients were divided into three groups. Patients of group $1(n=20)$ received for anti-inflammatory purposes tocilizumab at a dose of $600-800 \mathrm{mg}$. Patients in group 2 $(n=82)$ received pulse therapy with methylprednisolone according to the scheme: $1000 \mathrm{mg}$ IV for 3 days, $500 \mathrm{mg}$ IV for the next 3 days, $250 \mathrm{mg}$ IV for 3 days and $125 \mathrm{mg}$ for 3 days with CRP monitoring. Patients in group 3 $(\mathrm{n}=20)$ received dexamethasone $6 \mathrm{mg} /$ day.

In group $1-3$ patients required oxygen therapy through a face mask at a flow rate of $151 /$ min, 3 - invasive mechanical ventilation, 14 - non-invasive ventilation in CPAP mode. In group 2, there were 52 patients 
who received non-invasive ventilation in CPAP mode and 30 most severe patients who received invasive ventilation through the endotracheal tube. In the group of 3 - 10 patients were on streaming oxygen therapy through a face mask with a flow rate of $15 \mathrm{l} / \mathrm{min}, 9$ patients received non-invasive pulmonary ventilation in CPAP mode and 1 - invasive ventilation. All patients underwent NIV through a tight-fitting face mask with Newport E 360t, Dräger Carina, Resvent RS 300, Monnal 75t, Graph Net and Extend XT with assessment of ventilation parameters and pulmonary mechanics: $\mathrm{Vt}(\mathrm{ml}), \mathrm{MV}(\mathrm{l} / \mathrm{min}), \mathrm{f}$ (for $1 \mathrm{~min})$, Pin $\left(\mathrm{cm} \mathrm{H}_{2} \mathrm{O}\right)$, Pmean $\left(\mathrm{cm} \mathrm{H}_{2} \mathrm{O}\right)$, PEEP $\left(\mathrm{cm} \mathrm{H}_{2} \mathrm{O}\right), \mathrm{FiO}_{2}(\%)$ using graphics monitors. The oxygen saturation index (OSI) was calculated by the formula:

\section{$\mathrm{OSI}=\left(\mathrm{FiO}_{2} * \mathrm{Pmean}^{*} 100\right) / \mathrm{SpO}_{2}$}

where $\mathrm{FiO}_{2}$ - fraction of oxygen in the gas mixture, Pmean - the average pressure in the airways.

The ROX index was determined by the formula:

$\mathrm{ROX}=\left(\mathrm{SpO}_{2} / \mathrm{FiO}_{2}\right) / \mathrm{RR}$,

where RR is the frequency of respiratory rate.

Data are presented as M [25-75]. Statistical analysis of the results was performed using the program "Sta- tistica 10". Significance of differences in indicators was assessed using the nonparametric Wilcoxon test. The results were considered reliable at values of $\mathrm{p}<0.05$.

\section{Results}

Markers of inflammation were evaluated on admission to the ICU. In group 1, the median CRP was $89.2 \mathrm{~g} / \mathrm{l}$, in group $2-64.2 \mathrm{~g} / \mathrm{l}$, and in $3-76.2 \mathrm{~g} / \mathrm{l}$, which is more than 10 times higher than normal values and did not differ significantly between groups $(\mathrm{p}>0.05)$. The level of IL-6 was also assessed, which in group 1 was $61.8 \mathrm{pg} / \mathrm{ml}$, in group $2-64.6 \mathrm{pg} / \mathrm{ml}$, and in group $3-46.5 \mathrm{pg} / \mathrm{ml}$ without significant differences between groups $(\mathrm{p}>0.05)$. The level of ferritin in all groups exceeded normal values, which together confirms the presence of a hyperinflammatory reaction of the body and the severe course of COVID-19 in the examined patients. The level of procalcitonin in the examined patients at the time of hospitalization was at the upper limit of normal (Table 1).

At hospitalization of patients to ICU the following laboratory indicators were estimated: total protein, urea, blood creatinine. According to these indicators, patients in all groups had normal values and did not differ significantly. The level of hemoglobin and leukocytes also corresponded to normal values and did not differ between groups significantly $(\mathrm{p}>0.05)$ (Table 2$)$.

Table 1

Indicators of inflammation in patients depending on the option of anti-inflammatory therapy Me [25-75]

\begin{tabular}{|c|c|c|c|c|}
\hline Indicator & Group 1 & Group 2 & Group 3 & Norma \\
\hline \multirow{2}{*}{ Ferritin, mcg/L } & 1076.0 & 1181.0 & 918.0 & $<350$ \\
& {$[540-1562]$} & {$[546.5-1739.0]$} & {$[352.0-1984.0]$} & $<6$ \\
\multirow{2}{*}{ C-reactive protein. g/L } & 89.2 & 64.2 & 76.2 & \\
\hline \multirow{2}{*}{ Procalcitonin. ng/mL } & {$[62.0-141.4]$} & {$[55.5-158.0]$} & {$[34.3-156.1]$} & $<0.5$ \\
\hline \multirow{2}{*}{ IL-6. pg/mL } & {$[0.2-0.4]$} & {$[0.2-0.5]$} & {$[0.3-0.7]$} & 46.5 \\
\end{tabular}

Table 2

Basic clinical and biochemical parameters of blood of examined patients Me [25-75]

\begin{tabular}{|c|c|c|c|c|}
\hline Indicator & Group 1 & Group 2 & Group 3 & Norma \\
\hline Hb. $g / L$ & $\begin{array}{c}120.0 \\
{[55.0-185.0]}\end{array}$ & $\begin{array}{c}128.0 \\
{[96.0-171.0]}\end{array}$ & $\begin{array}{c}128.5 \\
{[43.0-151.0]}\end{array}$ & $120.0-140.0$ \\
\hline $\begin{array}{l}\text { White blood cells. } \\
\qquad \times 109 / \mathrm{L}\end{array}$ & $\begin{array}{c}8.2 \\
{[3.6-21.2]}\end{array}$ & $\begin{array}{c}9.1 \\
{[3.1-22.6]}\end{array}$ & $\begin{array}{c}6.2 \\
{[2.8-13.0]}\end{array}$ & $4.0-9.0$ \\
\hline Glucosa, mmol/L & $\begin{array}{c}7.0 \\
{[4.2-20.3]} \\
\end{array}$ & $\begin{array}{c}7.0 \\
{[2.9-15.8]} \\
\end{array}$ & $\begin{array}{c}6.0 \\
{[3.7-17.2]}\end{array}$ & $3.3-5.5$ \\
\hline Protein, g/l & $\begin{array}{c}67.0 \\
{[61-77.5]}\end{array}$ & $\begin{array}{c}68.2 \\
{[61.0-78.0]}\end{array}$ & $\begin{array}{c}69.4 \\
{[69.3-69.5]}\end{array}$ & $54-77$ \\
\hline Urea, mmol/L & $\begin{array}{c}7.2 \\
{[3.6-26.2]}\end{array}$ & $\begin{array}{c}8.5 \\
{[4.5-30.4]}\end{array}$ & $\begin{array}{c}6.2 \\
{[4.0-13.5]}\end{array}$ & $3.5-10.5$ \\
\hline Creatinin, mcmol/L & $\begin{array}{c}89.0 \\
{[8.8-189.0]}\end{array}$ & $\begin{array}{c}96.5 \\
{[60.0-194.0]}\end{array}$ & $\begin{array}{c}110 \\
{[63.0-255.0]}\end{array}$ & $26-120$ \\
\hline
\end{tabular}

Because the development of a cytokine storm is characterized by hypercoagulable states and a high risk of adverse thromboembolic events, the examined patients were evaluated for D-dimer.

In group 1, it was $527.0[246.0-1478.0] \mathrm{ng} / \mathrm{ml}$, 2 - 880.0 [310.0-2126.0] ng/ml, 3-1990.0 [538.0-
4600.0] ng/ml. Therefore, the obtained results confirm the presence of hypercoagulation in the examined patients.

The saturation index (OSI) in group 1 was 18.0 [12.0-24.0], in group $2-12.0$ [10.9-18.0] and 14.0 [11.6-22.0] in group 3 and had no significant differences 
( $p>0.05)$. The obtained results indicate that patients of both groups have severe ARDS according to the Berlin criteria (2012), which requires respiratory support. The average airway pressure in group 1 was 16.9 [16.0-21.8] $\mathrm{cm} \mathrm{H} 2 \mathrm{O}$, in group $2-21.0$ [14.0-21.8] $\mathrm{cm} \mathrm{H} 2 \mathrm{O}$ and 13.6 [11.8-18.2] $\mathrm{cm} \mathrm{H} 2 \mathrm{O}$ in group 3 ( $\mathrm{p}>0.05)$.

After 5 days, patients examined re-evaluation of inflammatory markers to assess the effect of steroid therapy. The level of CRP in group 1 was 49.6 [35.263.1] g/l, group $2-61.1$ [36.2-320] $\mathrm{g} / \mathrm{l}$, and in $3-49.6$ $[13,9-136,8] \mathrm{g} / \mathrm{l}$ without significant differences between groups. That is, in the dynamics there is a tendency to reduce the CRP in groups. The value of procalcitonin in group 1 for 5 days was 0.74 [0.33-2.8], group $2-0.71$ [0.29-2.15], and in group $3-0.54$ [0.1-5.9]. The obtained data reflect the accession of a bacterial infection, which may be due to the use of immunosuppressive therapy. There was also an increase in the level of D-dimer in the dynamics in all groups, which is an unfavourable prognostic factor (Table 3 ).

Patients also underwent bedside ultrasound examination to determine hemodynamic status. Indicators were within normal limits and had no significant differences between groups ( $\mathrm{p}>0.05)$ (Table 4$)$.

Table 3

Indicators of inflammation on the 5th day in patients depending on the option of anti-inflammatory therapy Me [25-75]

\begin{tabular}{|c|c|c|c|}
\hline Indicator & Group 1 & Group 2 & Group 3 \\
\hline \multirow{2}{*}{ C-reactive protein. g/L } & 49.6 & 61.1 & 49.6 \\
& {$[35.2-63.1]$} & {$[36.2-320]$} & $0.73-136.8]$ \\
\hline \multirow{2}{*}{ Procalcitonin. ng/mL } & 0.74 & 0.71 & 0.54 \\
& {$[0.33-2.8]$} & {$[0.29-2.15]$} & {$[0.1-5.9]$} \\
\hline \multirow{2}{*}{ D-dimer. ng/mL } & 1755.1 & 7500 & 1689.5 \\
& {$[337-3907]$} & {$[295-7500]$} & {$[196-7500]$} \\
\hline
\end{tabular}

Table 4

Characteristics of hemodynamic status of patients in the examined groups Me [25-75]

\begin{tabular}{|c|c|c|c|c|}
\hline Indicator & Group 1 & Group 2 & Group 3 & Norma \\
\hline $\mathrm{EDV}, \mathrm{ml}$ & $\begin{array}{c}97.1 \\
{[55.7-225.3]}\end{array}$ & $\begin{array}{c}98.3 \\
{[55.7-222.9]}\end{array}$ & $\begin{array}{c}121.3 \\
{[55.7-146.3]}\end{array}$ & $80-150$ \\
\hline $\mathrm{ESV}, \mathrm{ml}$ & $\begin{array}{c}29.6 \\
{[11.3-98.3]}\end{array}$ & $\begin{array}{c}33.8 \\
{[37.9-80.8]}\end{array}$ & $\begin{array}{c}27.5 \\
{[7.9-51.2]}\end{array}$ & $30-40$ \\
\hline $\mathrm{SV}, \mathrm{ml}$ & $\begin{array}{c}64.7 \\
{[44.38-127.0]}\end{array}$ & $\begin{array}{c}64.1 \\
{[37.9-150.2]}\end{array}$ & $\begin{array}{c}91.3 \\
{[47.8-105.28]}\end{array}$ & $70-100$ \\
\hline $\mathrm{EF}, \%$ & $\begin{array}{c}67.9 \\
{[58.9-79.8]} \\
\end{array}$ & $\begin{array}{c}65.7 \\
{[56.7-80.7]} \\
\end{array}$ & $\begin{array}{c}76.0 \\
{[64.1-86.5]} \\
\end{array}$ & $55-75$ \\
\hline
\end{tabular}

After administration of tocilizumab at a dose of 8 $\mathrm{mg} / \mathrm{kg}$ body weight in group 1 once or twice (after 12 hours) in patients on oxygen therapy $(n=3)$ there was an improvement in the form of regression of respiratory failure and weaning from oxygen subsidy in 2 patients, 1 patient was transferred on mechanical ventilation due to the progression of cerebral insufficiency and hemodynamic disorders despite the positive effect on gas exchange parameters. Among patients with CPAP $(n=14)$, 12 hours after the introduction of tocilizumab, a positive effect was observed in the form of a reduction in the manifestations of ARDS. However, mortality was $64.3 \%$ (9 patients). In 8 patients the lethal outcome was due to the development of thromboembolic complications, and in 1 patient - septic shock. $35.7 \%$ (5 patients) recovered.
When using tocilizumab in patients with invasive ventilation $(n=3)$ clinical effect was observed in 1 patient: after 7 days of invasive ventilation successful extubation; 1 patient died on the third day, 1 - transferred to another hospital.

The overall mortality rate in group 2 was $59.8 \%$ (49 patients).

The structure of mortality was dominated by MODS 22 patients, the development of septic shock 15 patients, 5 patients were diagnosed with pulmonary embolism, 4 - stroke, 2 - bleeding.

In the group using dexamethasone mortality was $100 \%$. The structure of mortality was dominated by pulmonary embolism - 14 cases, shock -3 patients, stroke 2 cases and 1 bleeding.

Table 5

Frequency of adverse events in the examined groups (\%)

\begin{tabular}{|c|c|c|c|}
\hline Indicator & Group 1 & Group 2 & Group 3 \\
\hline PE & $8(40 \%)$ & $5(6.1 \%)$ & $14(70 \%)$ \\
\hline Septic shock & $1(5 \%)$ & $15(18.3 \%)$ & $3(15 \%)$ \\
\hline Stroke & $0 \%$ & $4(4.9 \%)$ & $2(10 \%)$ \\
\hline MODS & $0 \%$ & $22(26.8 \%)$ & $0 \%$ \\
\hline Bleeding & $0 \%$ & $2(2.4 \%)$ & $1(5 \%)$ \\
\hline
\end{tabular}

Calculating the relative risk of adverse events, in particular pulmonary embolism, significantly higher risks were obtained in groups 1 and $3\left[\mathrm{RR}_{12} 6.8\right.$ [2.7$\left.16.8] \mathrm{p}_{12}<0.0001, \mathrm{RR}_{23} 0.15[0.06-0,35] \mathrm{p}_{23}<0.0001\right)$. 
The relative risk of developing stroke had no significant differences between the groups [RR12 0.94

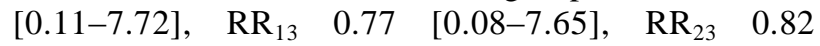
$[0.16-4,11] \mathrm{p}>0.05)$. There was also no significant difference between the groups in the relative risk of septic shock $\left(\begin{array}{lllll}\mathrm{RR}_{12} & 0.75 & {[0.26-2.22],} & \mathrm{RR}_{13} & 1.54\end{array}\right.$ [0.36-6.49], $\mathrm{RR}_{23} 2.04$ [0.66 -6.29] $\left.\mathrm{p}>0.05\right)$ and bleeding $\quad \begin{array}{lllll}\mathrm{RR}_{12} & 0.71 & {[0.04-14.03],} & \mathrm{RR}_{13} & 0.5\end{array}$ [0.02-11.42], $\mathrm{RR}_{23} 0.82$ [0.08-8.5] p>0.05). However, in group 2, a higher risk of developing kidney failure than in group $3\left(\mathrm{RR}_{23} 18.9\right.$ [1.2-29.7] $\left.\mathrm{p}=0.04\right)$, which is due to the severity of the disease and the development of MODS.

\section{Discussion}

This study confirms the benefit of anti-inflammatory therapy to improve outcomes in patients with COVID-19 pneumonia.

The choice of anti-inflammatory therapy in critical patients with COVID-19 remains open. In contrast to the results of the large RECOVERY RCT, in our case with dexamethasone in group 3, we obtained unsatisfactory results of intensive care, which was accompanied by $100 \%$ mortality. Salvarani et al. and Campochiaro et al. found no significant difference in mortality in patients receiving tocilizumab $[18,19]$. In contrast, several other studies have shown that tocilizumab is associated with a reduced risk of death and length of hospital stay [20-23]. The data obtained by us are consistent with the EMPACTA study in the form of a reduction in mortality to $64 \%$. Similar results were obtained when using pulse therapy with methylprednisolone.
Study limitations. The limitations of the study are related to a small sample of patients.

Prospects for further study. The study of the effect of ventilation regimens in patients with moderate and severe ARDS caused by SARS-nCoV-2 virus (COVID-19) on the morphological structure of the lungs will be further developed.

\section{Conclusions}

1. Severe coronavirus disease with the development of cytokine storm and respiratory distress syndrome is accompanied by a high mortality rate, which in our study was $63.1 \%$.

2. The use of the proposed options for immunosuppressive therapy can reduce the inflammatory response, as evidenced by a decrease in CRP in all groups on the 5th day of intensive care.

3 . The most favourable result was obtained in group 2, which used pulse therapy with methylprednisolone, and the mortality rate was $59.8 \%$.

4. The relative risk of PE was significantly higher in groups 1 and $3\left(\mathrm{RR}_{12} 6.8\right.$ [2, 7-16.8] $\mathrm{p}_{12}<0.0001$, $\mathrm{RR}_{23} 0.15$ [0.06-0.35 [ $\mathrm{p}_{23}<0.0001$ ), which gives grounds to confirm the presence of anticoagulant activity in methylprednisolone.

\section{Conflict of interest}

The authors declare that they have no conflicts of interest.

\section{Financing}

The study was performed without financial support.

\section{References}

1. Hardy, R. S., Raza, K., Cooper, M. S. (2020). Therapeutic glucocorticoids: mechanisms of actions in rheumatic diseases. Nature Reviews Rheumatology, 16 (3), 133-144. doi: http://doi.org/10.1038/s41584-020-0371-y

2. Xu, Z., Shi, L., Wang, Y., Zhang, J., Huang, L., Zhang, C. et. al. (2020). Pathological findings of COVID-19 associated with acute respiratory distress syndrome. The Lancet Respiratory Medicine, 8 (4), 420-422. doi: http://doi.org/10.1016/s2213-2600(20)30076-x

3. Meduri, G. U., Bridges, L., Shih, M.-C., Marik, P. E., Siemieniuk, R. A. C., Kocak, M. (2015). Prolonged glucocorticoid treatment is associated with improved ARDS outcomes: analysis of individual patients' data from four randomized trials and trial-level meta-analysis of the updated literature. Intensive Care Medicine, 42 (5), 829-840. doi: http://doi.org/10.1007/s00134-015-4095-4

4. Wu, C., Chen, X., Cai, Y., Xia, J., Zhou, X., Xu, S. et. al. (2020). Risk Factors Associated With Acute Respiratory Distress Syndrome and Death in Patients With Coronavirus Disease 2019 Pneumonia in Wuhan, China. JAMA Internal Medicine, 180 (7), 934. doi: http://doi.org/10.1001/jamainternmed.2020.0994

5. Zhou, W., Liu, Y., Tian, D., Wang, C., Wang, S., Cheng, J. et. al. (2020). Potential benefits of precise corticosteroids therapy for severe 2019-nCoV pneumonia. Signal Transduction and Targeted Therapy, 5 (1). doi: http://doi.org/10.1038/s41392-020-0127-9

6. Wang, Y., Jiang, W., He, Q., Wang, C., Wang, B., Zhou, P. et. al. (2020). A retrospective cohort study of methylprednisolone therapy in severe patients with COVID-19 pneumonia. Signal Transduction and Targeted Therapy, 5 (1). doi: http://doi.org/10.1038/ s41392-020-0158-2

7. Zha, L., Li, S., Pan, L., Tefsen, B., Li, Y., French, N. et. al. (2020). Corticosteroid treatment of patients with coronavirus disease 2019 (COVID- 19). Medical Journal of Australia, 212 (9), 416-420. doi: http://doi.org/10.5694/mja2.50577

8. Veronese, N., Demurtas, J., Yang, L., Tonelli, R., Barbagallo, M., Lopalco, P. et. al. (2020). Use of Corticosteroids in Coronavirus Disease 2019 Pneumonia: A Systematic Review of the Literature. Frontiers in Medicine, 7. doi: http://doi.org/10.3389/fmed.2020.00170

9. Dexamethasone in Hospitalized Patients with Covid-19 (2021). New England Journal of Medicine, 384 (8), 693-704. doi: http://doi.org/10.1056/nejmoa2021436

10. Fadel, R., Morrison, A. R., Vahia, A., Smith, Z. R., Chaudhry, Z. et. al. (2020). Early Short-Course Corticosteroids in Hospitalized Patients With COVID-19. Clinical Infectious Diseases, 71 (16), 2114-2120. doi: http://doi.org/10.1093/cid/ciaa601

11. Ye, Z., Wang, Y., Colunga-Lozano, L. E., Prasad, M., Tangamornsuksan, W., Rochwerg, B. et. al. (2020). Efficacy and safety of corticosteroids in COVID-19 based on evidence for COVID-19, other coronavirus infections, influenza, communityacquired pneumonia and acute respiratory distress syndrome: a systematic review and meta-analysis. Canadian Medical Association Journal, 192 (27), E756-E767. doi: http://doi.org/10.1503/cmaj.200645

12. Zou, L., Ruan, F., Huang, M., Liang, L., Huang, H., Hong, Z. et. al. (2020). SARS-CoV-2 Viral Load in Upper Respiratory Specimens of Infected Patients. New England Journal of Medicine, 382 (12), 1177-1179. doi: http://doi.org/10.1056/nejmc2001737

13. Orhanizatsiia nadannia medychnoi dopomohy khvorym na koronavirusnu khvorobu (COVID-19) (2020). Nakaz MOZ Ukrainy No. 722. 28.03.2020. Available at: https://zakon.rada.gov.ua/rada/show/v0722282-20\#Text 
14. Pro zatverdzhennia protokolu «Nadannia medychnoi dopomohy dlia likuvannia koronavirusnoi khvoroby (COVID-19)» (2020). Nakaz MOZ Ukrainy No. 762. 02.04.2020. Available at: https://zakononline.com.ua/documents/show/488336 658577

15. Pro vnesennia zmin do protokolu «Nadannia medychnoi dopomohy dlia likuvannia koronavirusnoi khvoroby (COVID19)» (2020). Nakaz MOZ Ukrainy No. 852. 10.04.2020. Available at: https://zakon.rada.gov.ua/rada/show/v0852282-20\#Text

16. Pro vnesennia zmin do dodatku 6 Standartiv medychnoi dopomohy Koronavirusna khvoroba (COVID-19) (2020). Nakaz MOZ Ukrainy No. 994. 30.04.2020. Available at: https://zakon.rada.gov.ua/rada/show/v0994282-20\#Text

17. Ranieri, V. M., Rubenfeld, G. D., Thompson, B. T., Ferguson, N. D., Caldwell, E., Fan, E. et. al. (2012). Acute respiratory distress syndrome: the Berlin Definition. JAMA, 307 (23), 2526-2633. doi: http://doi.org/10.1001/jama.2012.5669

18. Luo, P., Liu, Y., Qiu, L., Liu, X., Liu, D., Li, J. (2020). Tocilizumab treatment in COVID- 19: A single center experience. Journal of Medical Virology, 92 (7), 814-818. doi: http://doi.org/10.1002/jmv.25801

19. Sciascia, S., Aprà, F., Baffa, A., Baldovino, S., Boaro, D., Boero, R. et. al. (2020). Pilot prospective open, single arm multicentre study on off-label use of tocilizumab in patients with severe COVID-19. Clinical and Experimental Rheumatology, 38 (3), 529-532.

20.Somers, E. C., Eschenauer, G. A., Troost, J. P., Golob, J. L., Gandhi, T. N., Wang, L. et. al. (2020). Tocilizumab for treatment of mechanically ventilated patients with COVID-19. medRxiv 2020. doi: https://doi.org/10.1101/2020.05.29.20117358

20. Guaraldi, G., Meschiari, M., Cozzi-Lepri, A., Milic, J., Tonelli, R., Menozzi, M. et. al. (2020). Tocilizumab in patients with severe COVID-19: a retrospective cohort study. The Lancet Rheumatology, 2 (8), e474-e484. doi: http://doi.org/10.1016/s26659913(20)30173-9

22. Rimland, C. A., Morgan, C. E., Bell, G. J., Kim, M. K., Hedrick, T., Marx, A. et. al. (2020). Clinical characteristics and early outcomes in patients with COVID-19 treated with tocilizumab at a United States academic center. medRxiv 2020. doi: https://doi.org/10.1101/2020.05.13.20100404

23. Campochiaro, C., Della-Torre, E., Cavalli, G., De Luca, G., Ripa, M., Boffini, N. et. al. (2020). Efficacy and safety of tocilizumab in severe COVID-19 patients: a single-centre retrospective cohort study. European Journal of Internal Medicine, 76, 4349. doi: http://doi.org/10.1016/j.ejim.2020.05.021

Received date 03.08.2021

Accepted date 09.09.2021

Published date 30.09.2021

Vita Skoryk, Postgraduate Student, Department of Anesthesiology, Pediatric Anesthesiology and Intensive Care, Kharkiv Medical Academy of Postgraduate Education, Amosova str., 58, Kharkiv, Ukraine, 61176 E-mail: vitaskoryk@gmail.com 